\title{
Organismic spatiality: toward a metaphysic of composition
}

\author{
Tano S Posteraro \\ Department of Philosophy, Pennsylvania State University, University Park, State College, \\ PA 16801, USA; e-mail: tano.sage@gmail.com \\ Received 29 August 2013; in revised form 7 December 2013
}

\begin{abstract}
The task of this paper is the construction of a theory of organismic spatiality. I take as a starting point Gilles Deleuze's reference in The Logic of Sense to Gilbert Simondon's concept of the membrane. The membrane is a dynamically topological limit between the organism's milieus of interiority and exteriority-the first moment of organismic spatiality. It is the foundation of the organism as an entity spatially distinct from its environment. The membrane is discriminatory and asymmetric-a concept, I claim, best understood by way of a discussion of affectivity. To understand how the membrane brings the organism's interior milieu into contact with the outside requires us to analyze its capacity to affect and be affected by its environment. To appreciate the compositional implications of this affectivity, I bring the concept into conversation with Humberto Maturana and Francisco Varela's work on autopoietic systems theory. Conceived autopoietically, the organism's activity as a living system constructs its own milieu of exteriority. Just as it pulses to its rhythm of temporality, so too does the organism live its own space: the here, as opposed to the now, of organismic subjectivity.
\end{abstract}

Keywords: space, ontology, ecology, organism, Deleuze, Simondon

\section{Introduction}

"Our space is constituted through the sense we make of it, the mapping of our field of orientation."

Clair Colebrook (2005, page 195)

The task of this paper is the construction of a theory of organismic spatiality. Its structure is threefold: first, I take as a starting point Gilles Deleuze's reference, in The Logic of Sense, to Gilbert Simondon's (1995) concept of the membrane. The membrane serves, in this study, as a topological limit between what Deleuze, following Simondon, calls the organism's milieus of interiority and exteriority. ${ }^{(1)}$ It is the first moment of organismic spatiality: the foundation of the organism as an entity spatially distinct from its environment. Far from a passive boundary, however, the membrane is discriminatory and asymmetric - a concept, I claim, best understood by way of a discussion of affectivity. This will serve as the paper's second step: understanding how the membrane brings the organism's interior milieu into contact with the outside requires an analysis of its capacity to affect and be affected by its environment. Third, to properly appreciate the compositional implications of this affectivity, I bring the concepts at hand into conversation with Humberto Maturana and Francisco Varela's work on autopoietic systems theory. Together, these concepts constitute what I call a theory of organismic spatiality.

${ }^{(1)}$ Simondon deploys his conception of the membrane across the majority of his writing, from technological being and the transduction of crystals, to the individuation of living things. I am concerned here, however, only with the membrane's organismic connotations and implications. Hence, this concept will be read selectively and mobilized toward a purpose that is wholly my own, which is to say that the implications I derive from the membrane may appear at times antithetic to Simondon's own trajectories of thought. 


\section{The membrane}

In his invocation of the membrane Deleuze claims that, following the French poet and philosopher Paul Valéry, "it is necessary to understand that "the deepest is the skin" (Deleuze, 1990, page 103). This is because it is the surface, the skin, the membrane, or limit that brings a milieu of interiority into contact with what is exterior to it. "The internal and the external, depth and height, have biological value only through this topological surface of contact" (1990, page 103). Milieus converge topologically, simultaneously differentiated from, and placed into contact with, each other by means of the membrane between them. If its internal milieu, the system of relationships that structures the organism's body, is to interface with an environment outside of it, there must first exist some boundary between the two, some means by which the two are first separated. In the absence of such a separation, the organism is more a drop of water in a pond than it is one of the tadpoles inhabiting it. Milieu, ecology, environment: all are meant to denote the systems of relations that together constitute the context in question. The milieu of the human organism is, for example, defined in terms of the submilieus that constitute it: internal, external, intermediary, and annexed-organic structure, environment, the exchanges between and across the two, and the flows of energy the organism draws upon in sustaining itself. ${ }^{(2)}$ Although the organism's interior is composed of a number of divergent functional structures and rates of synthesis, the network of these organic rhythms, seen from the perspective of the organism - instead of, for example, the perspective of the ecosystem in which it plays a role, or of one of the constituent organs of that network - together composes a single milieu. Heart, lungs, liver, brain, and so on: a multiplicity of organic relations constitutes the human organism, itself but one element in a larger ecology of relationships, an ecosystem. The question of the membrane is therefore the question of the interface between two ecologies, between the organism's interior milieu and the relations into which it enters with entities and flows outside itself, its milieu of exteriority, ecology, or environment.

The individuality of the organism is not so much a mark of finitude as a relative and variable limit. ${ }^{(3)} \mathrm{A}$ limit must exist between them before two things can relate. But no organic limit is static or rigidly definitive, "because", in the words of Muriel Combes (2013, page 20), "insofar as any individual is capable of growth, what was exterior to it can become interior". Limits expand and contract. They distend, growing porous and less discriminatory, or shrink and become more selective, as the organism in question exerts the effort of living. It is for this reason that the membrane is a variable topological limit, and is to be opposed conceptually to the inelastic rigidity of an anisotropic boundary. The theoretical work done by an appeal to topology resides, for the purpose of this project, in its ability to think the fold. If it were, for example, the case that living beings had only solitary, single interiors, set apart from everything outside of them, then the fold would never come into play. This may in fact hold, to be fair, in the case of single-celled organisms (Simondon, 1995, page 224). But in more complicated individuals, milieus proliferate. What was originally the limit of an absolute interiority folds in upon itself, giving rise to a medial series of interiorities, each exterior to the other, and yet all interior to the organism as a whole. ${ }^{(4)}$ In terms more properly Simondonian, "the polarized membrane therefore folds its organic pellicule and curves around itself in

${ }^{(2)}$ I take these terms from Deleuze and Guattari (1988, page 313).

${ }^{(3)}$ Finitude connotes, for Simondon, of a lack of the potential to grow. Its borders are rigid, static.

${ }^{(4)}$ Consider the structure of a protein. Before a protein assumes its functional three-dimensional shape, protein molecules exist as linear chains of amino acids. As a result of the distribution of acids and bonds in the chain, the protein is capable of folding in a number of different ways, transforming a chain into a complicated arrangement of pleats and folds. What was initially a linear sequence of acids conforms, by folding, into a three-dimensional structure. Folded, the protein molecule is capable of distinguishing its interior from bodies external to it. See Bruce Alberts et al (2002). 
order to rediscover, at the terminus of this torsion, its own milieu of interiority". The fold is, in other words, responsible for the distinction between inside and outside, and this distinction is itself responsible for the very existence of an inside - as the outside of the outside, to adapt Deleuze's formula. ${ }^{(5)}$ To speak of the topology of the membrane is to denote precisely this: its productive flexibility, its capacity to fold back onto itself, to bifurcate and multiply, generating and complicating interior spaces.

A series of medial interiors are separated one from the other by the asymmetric polarization of the membranes between them. "The human body is thus characterized", in Anne Sauvagnargues's words, "by the diversity of its interior spaces, the digestive cavities remaining exterior to the blood, which itself turns out to be relatively external to the glands that discharge their secretions into its flux, and so on" (2012, page 67). The selective permeability of the membrane is why the kidneys can concentrate waste toxic to the organs with which they otherwise relate. The membrane is polarized. It lets pass one kind of body; it opposes another (Simondon, 1995, page 223). Wherever there is a selective point of contact between two spaces-wherever there is a distinction between what is made to pass from one space into the other, and what is allowed to traverse that boundary in the opposite direction - there is a membrane. ${ }^{(6)}$ This relatively broad conception of the membrane makes possible, as in the case of the human body, an analysis of nested interiorities: membranes within membranes. And yet, the dynamically intricate terrain of these multiple interiorities is nevertheless to be distinguished from a milieu of exteriority.

The membrane is relational through and through. It is this relativity that, beyond producing and configuring the organism's interior, actually organizes its external milieu as well, structuring it in accordance with the anatomy of the organism's inside. ${ }^{(7)}$ "The functional and active polarity of the membrane configures", in the words of Sauvagnargues, "the external milieu as much as it constitutes its internal milieu". Indeed, the very concept of interiority implies a spatiality external to it, a milieu relative to which an interior space can function as such. The individual cannot be, in other words, by itself alone. "It is always coupled or coordinated", in Steven Shaviro's words, "with a milieu ... and cannot subsist as a unity without it" (no date). Although the kidneys are, for example, relatively exterior to the arteries that feed them, they are worthless without a blood supply. "Unless we grasp the importance of its relation with an associated milieu, we do not understand what the reality of the individual consists in: ... by itself alone, it is an incomplete reality" (Combes, 2013, page 21). The question is, however, one of how the limit between the two configures the exterior space. It does this, I claim, by distinguishing in what is external to it, what can affect its milieu of interiority — what can be integrated into it, what is to be rejected as harmful—-from what is incapable of making a difference to it, of posing a problem to which the body in question can venture a response. This is the first distinction: what is affectively significant from what is not. It determines what is ecologically meaningful for a given organism, what is part of its world. The second distinction is nested within the first, and determines what is destructive and what is complementary or enlivening. Together, these distinctions are responsible for

(5) "The fold simultaneously produces interiority and exteriority, inside and outside, such that the inside is formed as 'the outside of the outside', to adapt Deleuze's beautiful formula" (Sauvagnargues, 2012, page 67; see also Deleuze, 1988a, pages 96-97).

(6) Although I confine my reflections here to the case of the organism, it is worth noting that this claim might apply more comprehensively. The existence of a membrane need not, in other words, imply the existence of a skin-like boundary. Entities as heterogeneously complicated as governments or corporations must nonetheless interface with bodies and flows outside of them. For more on the far-reaching implications of conceiving boundaries as porous membranes, see Stacy Alaimo (2010).

${ }^{(7)}$ There is no inside until there is a distinction: interiority emerges out of a spatial bifurcation, a separation between two spaces one side of which becomes interior to the other. 
the configuration of the organism's world. "The polarity of the membrane distinguishes", in Sauvagnargues's words, "the favourable (which it integrated and retains) from the unfavourable (which it avoids and rejects) in a Spinozist manner" (2012, page 67). But Sauvagnargues does not pursue the richness of this connection, opting instead to sketch the temporal implications of Simondon's concept of membranic spatiality. ${ }^{(8)}$ This is no criticism; a sustained meditation on the composition of space is simply outside of her essay's purview. ${ }^{(9)}$

Indeed, reading Spinoza's theory of affectivity into Simondon's concept of the membrane pushes the composition of spatiality beyond the borders of Simondon scholarship and into the realm of an organism-specific theory of space. This conjunction of Simondon with Spinoza sets the present study apart from Mark Hansen's well-known (2001) work on the topic as well. ${ }^{(10)}$ Hansen's concern lies primarily with Deleuze's misappropriation of Simondon. He argues that Simondon's concept of individuation implies a distinction between the meta-stability of a preindividual domain and the individual itself as an ongoing process of coming-to-be only in concept. This is to say that the process of living is the process of individuation, and that the process of individuation is itself an ongoing coevolution between individual and milieu. The two are distinguishable in concept, not reality. But Deleuze transcendentalizes the preindividual, affording it an ontological status all of its own, a move that makes of individuation the actualization of a transcendental field (one distinct from the other) instead of an ongoing mediation between two entangled, coevolving terms. ${ }^{(11)}$ As a consequence, Deleuze falls prey, by Hansen's account, to the strictures of what Simondon calls hylomorphism: a model of individuation that presupposes, in Simondon's own words, "the existence of a temporal succession: first there is the principle of individuation, then this principle undertakes an operation of individuation, and finally the constituted individual appears" (2009, page 5). ${ }^{(12)}$ In Deleuzian terms, first there is the virtual-transcendental field of individuation, then there is the process of integration, and finally the actualized body appears. ${ }^{(13)}$ This gets Simondon wrong. The individual is not initially indeterminate, and fully determined subsequently; the individual is caught up from the beginning in an ongoing process of individuation (Chabot, 2013, page 76). This move is important for Hansen's project inasmuch as he needs first to free Simondon from the misguided overtones of a Deleuzian interpretation before he can mobilize the theory of individuation for his own purposes. Criticism aside, Hansen is right to claim for Simondon an ongoing processual relation between individual and milieu. The milieu does not fully individualize the individual in one fell swoop,

${ }^{(8)}$ She concludes her analysis by invoking the "chronogenetic trails" of past and present opened by the membrane's spatial distinctions (2012, page 70).

${ }^{(9)}$ Indeed, the last words of Sauvagnargues's article are: "From the transductive logic of individuation, we are led to a complex and phased temporality, producer of its own past and its own capacity for the future" (2012, page 70). I am led, however, not to a complex temporality, but rather into the affective mechanism by which the membrane works to organize the milieus with which it is associated.

${ }^{(10)}$ As criticism is not the aim of my paper, I treat Hansen's work only briefly, in order to better articulate the novelty of the present contribution.

${ }^{(11)}$ In Hansen's own words: Deleuze misunderstands Simondon because "First, Simondon's concept of individuation does not introduce a division between a molecular domain (intensity) and a molar one (extensity) so much as it mediates between such domains.... Second, Simondon's understanding of individuation is not so much transcendental as it is systemic and recursive; or rather, it is transcendental only because it is systemic and recursive" (2001, no page number).

${ }^{(12)}$ This is the hylomorphic claim that matter is formed applied to individuation: the individual is first indeterminate and only later determined by the imposition of some principle, more as an application than a process.

${ }^{(13)}$ Now, whether or not this is an accurate portrayal of Deleuze's ontology is another issue altogether. It is my opinion that one can plug Deleuze's understanding of the membrane into connections with other concepts without taking a lateral detour through its implications for the rest of Deleuze's ontology. 
and neither does the individual configure completely the layout of its milieu. ${ }^{(14)}$ The two coevolve. ${ }^{(15)}$ As was, however, the case with Sauvagnargues, so too with Hansen: the goal here is not to move beyond Simondon, not to plug his concepts into productive connections with others, but to sketch rigorously the foundation for, and implications of, the concepts already at hand. ${ }^{(16)}$ Hansen concludes by reading what he takes to be a Simondonian theory of individuation purified of Deleuze's misuse alongside Simondon's model of information (a model, Hansen argues, ignored in Deleuze's treatment) in order to better theorize the process of becoming that characterizes the living body.

Elizabeth Grosz's “Deleuze, Ruyer, and becoming-brain: the music of life's temporality" (2012) concerns itself with a similar conceptual constellation, but fails, again, to push these concepts forward. Doubtless, her synthesis of Ruyer's work on single-cell organisms with Deleuze's metaphysics of incorporeality and the subjectivity of the brain is brilliantly done. But its result is a new take on neither Ruyer nor Deleuze. It is a more rigorous articulation of Deleuzian theory by way of a lateral reading: alongside Ruyer, Uexküll, and Bergson, what may have otherwise seemed like dense, foreboding, and counterintuitive Deleuzism, comes to seem rather concrete, scientifically substantial, and provocative. This is important, even necessary, work. But I am interested in rearticulating neither Simondonian nor Deleuzian theory. I take, instead, Deleuze's (admittedly selective) reading of Simondon's concept of the membrane as a stepping-stone, moving from originary spatial differentiation into the affective mechanisms by which organisms configure their environments. Indeed, the note on which Grosz concludes is precisely the point of departure for the present study: she writes that life embodies a "becoming-brain" to the extent that "the brain is a site for the entwined connections between and transformations of the inside and the outside" (2012, page 9). It is in these connections and transformations, Grosz suggests, that work in the area will find its path forward. In order for me to do so, to move from the first moment of organismic spatiality into its apparatus of external organization, I now turn to an analysis of Spinoza's concept of affect. ${ }^{(17)}$

The invocation of affectivity is not, however, necessarily novel. Indeed, nonrepresentational theories of geography (NRT) have long celebrated affectivity's significance in spatial experience. NRT foregrounds the lived body's entanglement with the world, the way its moods and practices alter its experiences, and the way it is affected by that world on an unconscious, presubjective level (MacPherson, 2010). NRT takes seriously the fact that the world is lived and mediated by the body, a product of the very world with which it is so irreducibly caught up. Affect is, expectedly, of central importance for NRT, eager as it is to move away from the individual and toward the transindividual, the preindividual, the intersubjective (Waterton, 2012, page 69). Theorizing a way forward, Emma Waterton claims that there still remains much work to be done in conceptualizing the active role played by affect in the composition of space. "The agency", she writes, "of landscapes, affect,

(14) Indeed, the claim that individuation happens as if all at once effaces individuation itself, for it leaves unexplained how it is that the individual is supposed to be formed, just as it leaves unexplained how it is that this individual is supposed to distinguish itself (or come to be distinguished) from its milieu (see Simondon, 1992, page 299).

${ }^{(15)}$ In section 4, I marry the processual implications of this reading to autopoietic enactivity.

(16) This is not to say that Hansen does not accomplish these kinds of connections. He certainly does. He reads William Burroughs's literary ruminations on recent work in endosymbiogenesis in order to better articulate his position on Simondon. But he does not push the Simondonian concepts themselves. He purifies them of a bad Deleuzian reading and retheorizes them in association with others.

${ }^{(17)}$ It is in this analysis, as well as the synthesis with autopoietic systems-theory in section 4, that I aim to elevate the present study above what might otherwise be taken to be merely noncreative, secondary literature. 
and sensuous experience ... is too excessive and complex for us adequately to theorize" (2012, page 72; cf Morton, 2005). Affect is not sufficiently captured by the methodology of geographical analysis. And understandably so: the task of NRT is to understand space, not merely by visualizing (and thereby representing) it, but by foregrounding the role played in the experience of space by the lived body, its moods, and practices. It is difficult to fix the nature of affect itself-for what is at stake is precisely the extent to which affect figures into one's experience of space. This will be the contribution of the present study: I claim that the role played by affectivity in spatiality runs deeper than bodily experience; affect actually constitutes the mechanism by which space is composed. ${ }^{(18)}$ A step back is therefore required, from geography into philosophy, from the affective experience of space to the nature of affect itself. It is in this latter analysis that the role the living being plays not only in the experience, but in the very composition of its space, will come into relief. Before this experience can be adequately theorized, it is necessary first to understand the affective mechanism of spatial composition.

\section{Affectivity}

Affectivity refers, for Spinoza, to the changes in a body's power of action. "By affect", he writes, "I understand affections of the body by which the body's power of acting is increased or diminished" (1994, page 154). In John Protevi's terms, "affect is what a body can do and what it can undergo" (2011, page 393). Bodies compose with others, whether favorably or not. In these compositions, they enact and undergo changes in power. Thus, affect is a thoroughly relational concept: to increase one's power of acting, one must enter into a complementary relation with something external to oneself; when the relation is decompositional, one's power diminishes (Deleuze, 1988b, pages 49-50). What it means to affect another body is the inverse: when I enter into a relation that changes the power of another body, I am affecting it. Regardless of the direction of this movement, the relation is primary: whether affecting or affected, the body in question must relate with a component of its exterior milieu. ${ }^{(19)}$ "Affect marks a body's belonging to a world of encounters" (Gregg and Seigworth, 2010, page 2, emphasis in original). It is, at its core, a relational concept. A body's affects are defined by the environment with which that body relates, even if the environment is, in turn, defined by the affects it is capable of producing. "The capacity of a body is never", in other words, "defined by a body alone but is always aided and abetted by, and dovetails with, the field

${ }^{(18)}$ Doubtless, the composition and experience of space are bound up one with the other. But I take it that the claim that affect figures into the genesis of space itself, prior to the advent of experience (or perhaps situated recursively within it), constitutes a contribution to this domain of theory beyond analyses of the way affect colors spatial experience. For example, good work is done in theorizing the different nonrepresentational experiences of a given space by Paul Stenner, Andrew Church, and Mark Bhatti (2012). But this work fails to move beyond the way a space is experienced in order to get at the way it is composed, constituted, structured, configured. Thus, the implicit claim is that space is as it is, but that we experience it in certain ways. My argument is more radical: not only do we experience space differently, but we actually construct it as well. Similarly, Paul Simpson theorizes the way embodied spatial experiences are simultaneously constrained by, and imbricated with, their milieux in his recent paper "Ecologies of experience: materiality, sociality, and the embodied experience of (street) performing" (2013). But again, this is an analysis of the roles played by affect and the body in constraining the experience of a space. My aim here is to get beneath spatial experience; indeed, to found spatial experience in the compositional activities that underlie it.

${ }^{(19)}$ While Spinoza's concept of affect culminates in an analysis of bodily passions (joy, sadness), it is the primacy the concept affords to relations between a body and what is external to it that I wish to emphasize here. By no means do I intend for this to serve as a comprehensive representation of Spinoza's theory of affect. Instead, I take the concept as a starting point and push it into territory foreign to Spinoza's own trajectory of thought, in order to draw from it a set of implications indispensible to the present study. 
or context of its force-relations" (2010, page 3 ). It is therefore only in its relations with its environment that one learns what a body can do and undergo.

Affect, to be clear, is not feeling. Neither is it emotion or perception. I do often feel my affects, whether enthusiastically or otherwise, but "affect extends beyond feeling" (Protevi, 2011, page 395). This is because feeling, emotion, and perception all designate the subjective appropriation of what is originally an unconscious modification of the body's power to act (Massumi, 2002, pages 27-28). "Affect", writes Protevi, "has two registers. First, it is being affected, that is, undergoing the somatic change caused by encounter with an object" (2009, page 49). And somatic change need not involve conscious perception. "Second", he continues, "affect is the felt change in power of the body ..., felt as sadness or joy" (page 49). The second moment of affect is therefore better understood as emotion or perception. Pain is a feeling, a subjective response to a bodily affect. But that bodily affect is primary. Therefore, when I invoke the concept, I intend what Protevi refers to as its first register, although in many cases (and in most human ones) the two registers bleed into each other. This means that a milieu of exteriority is constituted not by what a given organism is capable of perceiving in it, not what it is capable of feeling, but rather by what it is capable of registering affectively (in a foundationally somatic sense). To take a simple example, tissue damage is, in Protevi's terms, "an objective phenomenon that is at first registered unconsciously, triggering reflexes, and then shows up as the conscious sensation of pain" (2009, pages 45-46). Pain is, therefore, the feeling of a change in bodily integrity. ${ }^{(20)}$ That underlying change is the affect, and is (at least initially) unconscious.

In $A$ Thousand Plateaus, Deleuze and Guattari proclaim that "we know nothing about a body until we know what it can do, in other words, what its affects are" (1988, page 257). I hasten to add that we know nothing about its milieu until we know what a body can undergo, by what it can be affected. Take the ant (Myrmica ruginodis), for example. Its visual capacities are relatively rudimentary; yet, if the necessary perceptual cues are present, the ant is capable of navigating a spatial field without relying too heavily on the pheromones it uses to mark its territory. Ants rely primarily on visual cues above them, registering differences in sky and canopy and adjusting their travel trajectory accordingly (Cammaerts, 2012; cf Collett and Graham, 2010). To play a role in the ant's spatial milieu, a body or force must be able to affect the ant in a way it is capable of registering - filtered through the affective porosities of the ant's membranes. To take a relatively superficial example, an airplane in flight over the ant is not registered because it does not make significant enough a difference to its perception of the sky. Neither does its fuel emission affect the ant's olfactory system. As a consequence, the airplane plays no real role in the ant's environment. Indeed, for all practical purposes, from the perspective of the ant the airplane does not exist at all. If it is to participate in the ant's milieu, it can only do so by means of the ant's own capacities to be affected. One could, however, imagine a difference made, as a vulgar kind of butterfly effect, in the air pressure surrounding the airplane. This difference might trigger, as a result, a change in local weather patterns - the airplane's path perhaps pushing intensities in temperature and pressure past their critical thresholds and activating the potential for a change in wind and cloud behavior. This change might, in turn, bring about an increase in precipitation and a subsequent softening of the soil of some particular area. The newly softened soil might play, as a consequence, some role in the way a colony of ants forge a path to their destination (Stadler and Dixon, 2005). The airplane, in this hypothetical example, may indeed affect the ants, influencing the way they navigate a territory, but it can do so only within the strictures of the ants' own affective architectures, their own spatial landscapes. The ants do not, therefore, register the

${ }^{(20)}$ Psychological disorders aside, affect is the condition for the possibility of feeling. One cannot feel consciously what does not first affect one on an unconscious level. 
airplane as the massive, airborne vehicle that it is (for humans capable of using and perceiving it as such); they register only a difference it might make in the texture of soil and perhaps in the concentration of other organisms in the area as a result. And in so doing, it is the ants' own affective capacities that are responsible for the organization of their external spaces. Their bodies - the affective porosity of their membranes - shape and color their ecologies.

The idea that an organism's capacities determine the relevant features of its environment resonates with what James Gibson, in The Ecological Approach to Visual Perception, refers to as affordances and abilities (1979, pages 127-146). Tying affordances to abilities (or affects) nuances the concept by adding to the discourse of affect variations in the environment's own aptitudes. The way an organism's environment gives itself to that organism is an affordance. "The affordances of the environment are", in Gibson's own terms, "what it offers the animal, what it provides or furnishes, either for good or ill" (page 127, emphases in original). Affect and affordance are codefining, which "implies the complementarity of the animal and the environment" (page 127). An airplane, as I have shown, can offer itself as a means for transportation only to organisms capable of purchasing tickets and reserving seats. These latter capacities determine the airplane's set of affordances. An airplane affords humans a means for transportation, but only because they are, in the first place, capable of operating airplanes. It might - as in my earlier scenario - afford ants a change in soil texture. It might afford birds the potential for high-altitude collisions. Its affordances vary relative to the affective capacities of whichever organisms relate with it. Affect and affordance are like sound and auditory perception. One hears only the sounds one's ears are capable of registering. Affordances are tied to affect, in other words, the way sounds are tied to their perception. ${ }^{(21)}$

Beyond adding nuance to the concept of affect, an analysis of affordances also foregrounds the primarily spatial relation between an organism and its environment. "The surface of a pond or lake may not afford a large animal a walking medium", to take an example from Delanda, "but it does to a small insect which can walk on it because it is not heavy enough to break through the surface tension of the water" (2002, page 63). For an organism like a giraffe - too large to walk on its surface and unable to swim - a sufficiently large body of water defines the boundary of a traversable space. ${ }^{(22)}$ It is a limit. While it might require a change in navigational activity, water is not, on the other hand, a barrier to the spatial extension of an elephant's milieu. ${ }^{(23)}$ For sufficiently small insects, there is no reason to suppose a locomotive distinction between water and soil at all. Spatially, they are continuous. The difference between them would have to lie in other affordances. And it does, for soil affords an insect different dietary possibilities, as well as different predatory threats (among a vast array of other things), than does the surface of a pond. The benefit of these concepts is the circumvention of the question of the environment's actual properties, as if it were a single, consistent thing for all bodies. While a pond's depth, for example, remains constant across organisms, in terms of what that pond affords a given organism, it has no one, true nature. ${ }^{(24)}$ Put differently, horizontality, flatness, extension, and rigidity may be physical properties of a given surface, but as an affordance of support for a species of animal, "they have to be measured relative to the animal" (Gibson, 1979, page 127, emphasis in original).

${ }^{(21)}$ Sound is the perception of vibration. In the absence of perception, there are no sounds, just frequencies.

${ }^{(22)}$ This example is, of course, speculative. It is not intended as a serious comment on the nature of giraffes. I invoke it only to make clearer the idea that the affordances of one's environment define its spatial landscape.

${ }^{(23)}$ Elephants are sophisticated swimmers.

(24) "[Physical properties] have unity relative to the posture and behaviour of the animal being considered. So an affordance cannot be measured as we measure in physics" (Gibson, 1979, pages 127-128). 
Different organisms organize one and the same physical landscape in different ways, and it affords those organisms correspondingly different possibilities.

I noted the twofold spatial significance of affective capacity: first, the distinction between what a given organism can and cannot enter into relation with; and second, the distinction made between favorable and unfavorable relations. In turning now more directly to the second, it is worth taking a detour through Henri Bergson's philosophy of perception. Perception, for Bergson, "is the measure of our possible action upon bodies: it results from the discarding of what has no interest for our needs, or more generally for our functions" (2004, page 30). The universe is vast, and perception is selective - a spotlight whose glow can illuminate only a narrow fraction of the world's shadows. The body's capacities narrow an overwhelming number of ecological possibilities down to a sliver of affectively viable space. Sensation is reductive. Objects reflect only, in Bergsonian terms, my body's possible action upon them (2004, page 7). They mirror the ways my body can be affected. My environment is, however, constituted not only by the ways I can be affected, but also by the force and nature of those affects. It is constituted, in other words, by the distinction between what affects me favorably and what does not, as well as the distinction between what affects me forcefully and what makes only the weakest of impressions. Objects therefore "take rank in an order corresponding to the growing or decreasing powers of my body" (page 6).

In terms decidedly phenomenological, Bergson describes the way objects seem to grow indifferent as he recedes from them. Conversely, "the more I narrow this horizon, the more the objects which it circumscribes space themselves out distinctly according to the greater or less ease with which my body can touch and move them" (page 6). I can grasp, for example, the handle of a mug, manipulating it usefully. As a consequence, handles appear to me inviting. They are practical. This is a function of spatial scale and the affects it allows me. This is, to my mind, the ecological import of Bergson's theory of perception. The affects that constitute a body determine the way it shapes its environment, not only physically (as in its environment's affordances), but also perceptually (as in the way objects appear to it). Another way to understand this claim is virtually. Perception is like an echolocative tool. It maps the world for us in terms of the capacities we have to utilize its constituent features. If it is hungry, the bat ignores rocks and cobwebs, searching instead for creatures upon which it might prey. But if it is tired, the bat ignores those creatures in favor of the nooks into which it might nestle and sleep. Echolocation provides it with a virtual image of an environment tailored to its needs and functions, its affects. The organism's environment is therefore something of a virtual image, a reflection of the way the organism interacts with the world. '[Perception] is akin to a kind of 'searchlight' governed by our ongoing needs that 'carves out' portions of 'sensible reality' by identifying possible relationships that might serve as footholds in a mobile, ever changing reality" (Brown and Tucker, 2010, page 235). This is because "our space is constituted", to borrow a line from Claire Colebrook, "through the sense we make of it, the mapping of our field of orientation" (2005, page 195). To say, however, that an organism's environment is configured by its affective capacities is also to say that the organism composes or synthesizes its environment in the very act of making sense of it. Adding to the language of porosity a vocabulary of sense-making makes clearer the fact that the composition of space is not a wholly passive affair.

Before endeavoring to synthesize affective-membranic spatiality with autopoietic sensemaking, it is worth taking stock of the concepts already developed. I began with Deleuze's reading of Simondon's concept of the membrane. The membrane, to reiterate, founds the distinction between inside and outside, setting the organism apart from its environment and thereby constituting externality as meaningful space. But beyond setting the two terms apart from each other, the membrane also brings one into relation with the other. In bringing 
membranic space into conversation with Spinoza's theory of affectivity, I developed the mechanism of this relation. The organism determines the structure of its environment in terms of how that environment is capable of affecting the organism. Different organisms are affected in different ways by one and the same physical space, and so they come to live very different spatialities. Turning first to Gibson, and then to Bergson, I nuanced the concept of affect-specific spatiality: first, in terms of the affordances offered by the space in question; and second, in terms of the way a given organism not only constructs, but also comes to perceive that space. Together, these concepts constitute what is, to my mind, a novel contribution to a theory of organismic spatiality. But more work remains to be done. To delineate more precisely the mechanisms by which an organism actively constitutes its milieu of exteriority, playing an active role in the construction of its environment, I turn now to the concept of sense-making, a concept that comes from the autopoietic systems theory of Maturana and Varela. This turn represents the last term of an ongoing conceptual synthesis the aim of which is a robust theory of the living composition of space: Deleuze, Simondon, Spinoza, Gibson, Bergson, and now the biology of autopoiesis.

\section{Autopoiesis}

Autopoiesis is a neologism introduced in 1971 by Chilean biologists Maturana and Varela to describe the self-producing, organizational activity of living systems (Varela, 1992; cf Maturana and Varela, 1980). ${ }^{(25)}$ They begin with the bacterial cell as the simplest instantiation of autopoietic life. As a system, the cell produces, by way of a continuous process of chemical reaction, the components necessary to distinguish it from its domain. The cell is an autopoietic system insofar as (1) its membrane organizes a network of components that define the cell as a distinct entity, and (2) its components are themselves involved in the regeneration of the boundary responsible for producing them (Varela, 1992, page 5). To speak, then, of organismic autopoiesis is to speak of the organism's capacity to produce itself, to self-organize. Organisms are, by this account, machinic unities. Adopting a vocabulary of components, input, output, structure, and production, Maturana and Varela convert talk of organisms into talk of machines. ${ }^{(26)}$ As machines, organisms are organized by means of a particular set of relations that structure their components. It is, I think, worth quoting here the canonical definition of an autopoietic machine:

"The relations that define a machine as a unity, and determine the dynamics of interactions and transformations which it may undergo as such a unity, constitute the organization of the machine. The actual relations which hold among the components which integrate a concrete machine in a given space, constitute its structure" (Maturana and Varela, 1980, page 77).

A machine's organization refers to the dynamic capacities of its component relations. Its structure is the set of actually instantiated component relations that define the organism as a unified body, distinct from a larger milieu with which it must relate processually if it is to survive. Taken together, organization and structure cover the productive capacities of the machine, its poiesis. The fact, however, that it produces itself, that it is autopoietic, is embodied in the way the network of processes that define the machine

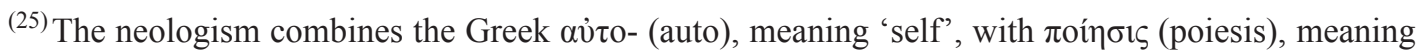
'production' or 'creation', to refer to the way living systems produce and maintain themselves over time.

(26) To understand the organism as a machine is not to reduce it to mechanistic principles, but rather to concretize it by means of a robust set of conceptual determinations. That life is beautiful ought not to render it any less comprehensible - and if a machinic conceptual apparatus makes the organic world less inscrutable, then so much the better for that beauty. For the purposes of the present study, however, a brief foray into Maturana and Varela's conceptual grammar will suffice. 
(its structure and organization) "through their interactions and transformations continuously regenerate and realize the network of processes (relations) that produced them" (Maturana and Varela, 1980, pages 77-78). Organismic life consists therefore in activity, in the fact that it must constantly realize itself if it is to continue to persist. But more specifically, the organism is an autopoietic machine because its organization is, as is so clear in the case of cellular life, both cause and effect of its activity as a living system.

In autopoietic terms the organism is operationally closed, but informationally open. The autopoietic system can, in other words, receive information from its environment (it is informationally open), but only information that is first made meaningful by the system's own capacities (it is operationally closed). ${ }^{(27)}$ Conceiving the organism as an autopoietic machine makes clear the fact that it is actively implicated in the composition of its spatial milieu. It does not just happen to inhabit an environment tailored to its bodily affects. The organism enacts its own identity by producing itself; and in producing itself, the organism inhabits a space of its own. Consider, for example, the operational closure of the nervous system and its color-perceptual implications. The nervous system communicates changes of state to the organism of which it is a part only by interacting with an environment outside it. It is structurally open to this environment.

This much is obvious. But it is also operationally closed, "for in each interaction it is the nervous system's structural state that specifies what perturbations are possible and what changes trigger them" (Maturana and Varela, 1992, page 169). The system's network of processes is set into motion by a perturbation from the outside (it is structurally receptive), but the referents of its activity remain internal to the system itself (it is operationally recursive) (Varela, 1992, page 10). In the perception of color, an optical image is formed by the machinery of the eye and projected onto a thin layer of photosensitive neurons, the retina. These cells are part of the central nervous system. The visual apparatus - its photoreceptors, rods, cones, and corresponding circuitry-works by first transforming the initially optical image into chemical and electrical information, and then by transmitting those signals to the brain through the optic nerve (Fairchild, 2005, page 4). If the system as a whole, however, is only structurally receptive to its environment, if the system is operationally self-referential, then the consequences are inescapable: the images we form of the world outside us do not precede the process of their formation. The same patterns of light and reflectance "lend themselves", in Varela's words, "to a wide variety of color spaces, depending on the nervous system involved in that encounter" (1992, page 12). There can be no representational correspondence between the perception of color and the physical properties of one's environment. "Color is", on the other hand, "a dimension that shows up only in the phylogenetic dialogue between an environment and the history of an active autonomous self which partly defines what counts as an environment" (page 12). Patterns of light and reflectance provide an occasion for perturbation. It is to these elements that the nervous system is structurally receptive. But once it is set into motion, the system itself forms the image of a color that in no way preceded the processes of that formation, a color that in no way corresponds to the external patterns that initiated the process. Indeed, "it is only after all this has happened, after a mode of coupling becomes regular and repetitive, like colors in ours ... that we observers, for ease of language, say color corresponds to or represents an aspect of the world" (page 12).

To speak at all of visual information prior to its reception in the body is misguided, a classic example of a cart placed in front of the horse meant to pull it. " 'Information,' as Varela,

${ }^{(27)}$ Cf Maturana and Varela (1992, page 47): “The most striking feature of an autopoietic system is that it pulls itself up by its own bootstraps and becomes distinct from its environment through its own dynamics, in such a way that both things are inseparable." 
Evan Thompson, and [Eleanor] Rosch put it in The Embodied Mind, is not 'a prespecified quantity, one that exists independently in the world and can act as the input to a cognitive system'" (Wolfe, 1998, pages 60-61). ${ }^{(28)}$ In striving to persist, the organism maintains its identity as an autopoietic system and "makes sense of the world from the perspective of that identity" (Thompson, 2007, page 153, my emphasis). What I have called composition, configuration, and constitution, Varela calls sense-making or the production of significance. "Living beings", to take another line from Thompson, "shape the world into meaningful domains of interaction and thereby bring forth their own environments of significance and valence" (2007, page 159).

The process of living, of striving to maintain or increase one's powers, is the process of partitioning indifferent features of the world into zones of the favorable, sites of the harmful, and deserts of neutrality. Sense-making, in Varela and Weber's words, "lays a new grid over the world: a ubiquitous scale of value" (2002, page 118; cf Thompson, 2007, page 158). To say that the organism lays a grid over the world is to say that what was originally a set of physical features becomes a milieu in which the attractive is distinguished from the repulsive, the valuable from the useless. What is crucial is the fact that "significance and valence do not preexist 'out there,' but are enacted, brought forth, and constituted by living beings" (Varela and Weber, 2002, page 118). Sense-making is a phrase intended to emphasize the activity of sensation. Living beings do not discover sense; they constitute it. Describing enaction as the laying down of a path in walking it, Varela borrows the words of Antonio Machado: "Wanderer the road is your footsteps, nothing else; you lay down a path in walking" (Thompson, 2007, page 13). The wanderer's path does not precede the trajectory of her steps. They are coemergent. There is a path only in the wanderer's walking it, and whichever direction he or she walks becomes his or her path. Wandering is path-making, just as life is sense-making.

The concept of sense is threefold, and involves sensibility, signification, and orientation (Thompson, 2011). Sensibility is the openness of a body to its environment, its receptivity to environmental cues. Signification is the value given to an environmental cue relative to bodily affect. And orientation is the ability of a body to comport itself in space relative to the presence of some significant thing. Even the simplest organisms can sense a difference in the presence of an attractant (a food). They can make sense of this difference in terms of their own needs, and orient themselves in space relative to what will benefit or harm them (Protevi, 2009, pages 16-17). The activity of this triple-movement is sense-making. It is also, at its core, the prerequisite for maintaining oneself as a living body. To say, then, that sense is enacted is to say that, prior to the autopoietic activity of a given body, a bacterium is neither attractive nor repulsive. It is in its relation with the bacterium - a body with respect to which sucrose is nutritious - that the sucrose molecule takes on meaning as food. "Sucrose", writes Thompson, "has significance or value as food, but only in the milieu that the organism itself brings into existence" (2011, page 119; see also Protevi, 2009, page 158). This milieu is enacted autopoietically, for it is only in striving continuously to reproduce its identity that the organism interacts meaningfully with otherwise indifferent features of its environment. It does so because it must do so, if it is to survive. Living, in Varela's famous formula, is sense-making.

The organism lives its own space. Its spatiality designates the fields across which its external ecologies are distributed. Organismic spatiality also designates the spatial dimension of subjectivity, a dimension that emerges out of the organism's membrane(s), its affective capacities, and its autopoietic enaction, the processual

${ }^{(28)}$ Environmental information must be constituted, composed, or enacted. And it is in this composition that I locate the active role for the organism in the organization and configuration of its ecology. 
activities of which serve as the conditions for the possibility of organismic space a kind of genetico-transcendental aesthetic. ${ }^{(29)}$ In this paper, I have endeavored to plug Deleuze's reading of Simondon's concept of membranic spatial differentiation into productive connections with Spinoza's discussion of affectivity, Gibson's concept of environmental affordance, Bergson's theory of perception, and Maturana and Varela's work in autopoietic systems theory. The result of these connections is, I hope to have shown, an overarchingly, coherent theory of the genesis of spatiality out of the activity of living things.

\section{References}

Alaimo S, 2010 Bodily Natures: Science, Environment, and the Material Self (Indiana University Press, Bloomington, IN)

Alberts B, Johnson A, Lewis J, Raff M, Roberts K, Walter P, 2002, "The shape and structure of proteins", in Molecular Biology of the Cell 4th edition, http://www.ncbi.nlm.nih.gov/books/NBK26830/

Bergson H, 2004 Matter and Memory translated by N M Paul, W S Palmer (Dover Publications, Mineola, NY)

Brown S D, Tucker I, 2010, "Eff the ineffable: affect, somatic management, and mental health service users", in The Affect Theory Reader Eds M Gregg, G J Seigwoth (Duke University Press, Durham, NC) pp 229-249

Cammaerts M-C, 2012, "The visual perception of the ant Myrmica Ruginodis (Hymenoptera: Formicidae)" Biologia 67 1165-1174

Chabot P, 2013 The Philosophy of Gilbert Simondon: Between Technology and Individuation (Bloomsbury Press, London)

Colebrook C, 2005, "On the specificity of affect", in Deleuze and Space Eds I Buchanan, G Lambert (Edinburgh University Press, Edinburgh) pp 189-206

Collett T, Graham P, 2010, "The visually guided routes of ants", in Spatial Cognition, Spatial Perception: Mapping the Self and Space Eds F L Dolins, R W Mitchell (Cambridge University Press, New York) pp 117-151

Combes M, 2013 Gilbert Simondon and the Philosophy of the Transindividual translated by T LaMarre (MIT Press, Cambridge, MA)

Delanda M, 2002 Intensive Science and Virtual Philosophy (Continuum, London)

Deleuze G, 1988a Foucault translated by S Hand (University of Minnesota Press, Minneapolis, MN)

Deleuze G, 1988b Spinoza: Practical Philosophy translated by R Hurley (City Lights Books, San Francisco, CA)

Deleuze G, 1990 The Logic of Sense translated by M Lester, edited by C V Boundas (Columbia University Press, New York)

Deleuze G, Guattari F, 1988 A Thousand Plateaus: Capitalism and Schizophrenia translated by B Massumi (University of Minnesota Press, Minneapolis, MN)

Fairchild M D, 2005, "Human color vision", in Color Appearance Models 2nd edition, Ed. M Fairchild (John Wiley, Chichester, Sussex) pp 1-34

Gibson J J, 1979 The Ecological Approach to Visual Perception (Houghton Mifflin, Boston, MA)

Gregg M, Seigworth G J, 2010, "An inventory of shimmers", in The Affect Theory Reader Eds M Gregg, G J Seigworth (Duke University Press, Durham, NC) pp 1-28

Grosz W, 2012, "Deleuze, Ruyer, and becoming-brain: the music of life's temporality" Parrhesia number $15,1-13$

Hansen M, 2001, "Internal resonance, or three steps towards a non-viral becoming" Culture Machine, http://www.culturemachine.net/index.php/cm/article/view/429/446

MacPherson H, 2010, "Non-representational approaches to body-landscape relations" Geography Compass 4 1-13

Massumi B, 2002 Parables for the Virtual: Movement, Affect, Sensation (Duke University Press, Durham, NC)

${ }^{(29)}$ I set this phrase against Kant's well-known transcendental aesthetic. For a more comprehensive distinction between the genetic foundation of spatiotemporality in organismic activity (especially metabolism) and Kant's transcendental aesthetic, see Protevi (2013, pages 179-196). 
Maturana H, Varela F, 1972, "Mechanism and biological explanation" Philosophy of Science $39328-382$

Maturana H, Varela F, 1980 Autopoiesis and Cognition: The Realization of the Living (D Reidel, Dordrecht)

Maturana H, Varela F, 1992 The Tree of Knowledge: The Biological Roots of Human Understanding (Shambhala, Boston, MA)

Morton F, 2005, "Performing ethnography: Irish traditional music sessions and new methodological space" Social and Cultural Geography 6 661-676

Protevi J, 2009 Political Affect: Connecting the Social and the Somatic (University of Minnesota Press, Minneapolis, MN)

Protevi J, 2013, "Mind in life, mind in process", in Life, War, Earth: Deleuze and the Sciences Ed. J Protevi (University of Minnesota Press, Minneapolis, MN) pp 179-196

Protevi J, 2011, "Ontology, biology, and history of affect", in The Speculative Turn: Continental Materialism and Realism Eds L Bryant, N Srnicek, G Harman (re.press, Melbourne) pp 393-405

Sauvagnargues A, 2012, "Crystals and membranes: individuality and temporality", translated by J Roffe, in Gilbert Simondon: Being and Technology Eds A De Boever, A Murray, J Roffe, A Woodward (Edinburgh University Press, Edinburgh) pp 57-72

Shaviro A, 2006, "Simondon on individuation" The Pinocchio Theory, http://www.shaviro.com/Blog/?p=471

Simondon G, 1992, "The genesis of the individual”, in Incorporations Eds J Crary, S Kwinter (Zone Books, New York) 297-319

Simondon G, 1995 L'individu et sa genèse physico-biologique (Presses Universitaires de France, Paris)

Simondon G, 2009, "The position of the problem of ontogenesis", translated by G Flanders Parrhesia number 7, 4-16

Simpson P, 2013, "Ecologies of experience: materiality, sociality, and the embodied experience of (street) performing" Environment and Planning A 45 180-196

Spinoza B, 1994 A Spinoza Reader: The Ethics and Other Works translated by E Curley (Princeton University Press, Princeton, NJ)

Stadler B, Dixon A, 2005, "Ecology and evolution of aphid-ant interactions" Annual Review of Ecology Evolution and Systematics 36 345-372

Stenner P, Church A, Bhatti M, 2012, "Human-landscape relations and the occupation of space: experiencing and expressing domestic gardens" Environment and Planning A 44 1712-1727

Thompson E, 2007 Mind in Life: Biology, Phenomenology, and the Sciences of Mind (Belknap Press, Cambridge, MA).

Thompson E, 2011, "Living ways of sense making" Philosophy Today 55 (issue supplement), $114-123$

Varela F, 1992, "Autopoiesis and a biology of intentionality", proceedings of a workshop held at Dublin City University, Dublin, 25-26 August, ftp://ftp.eeng.dcu.ie/pub/alife/bmcmg401/varela.pdf

Varela F, Weber A, 2002, "Life after Kant: natural purposes and the autopoietic foundations of biological individuality" Phenomenology and the Cognitive Sciences 197-125

Varela F, Thompson E, Rosch E, 1991 The Embodied Mind: Cognitive Science and Human Experience (MIT Press, Cambridge, MA)

Waterton E, 2012, "Landscape and non-representational theories", in The Routledge Companion to Landscape Studies Eds P Howard, E Wateron, I Thompson (Routledge, New York) pp 66-75

Wolfe C, 1998 Critical Environments: Postmodern Theory and the Pragmatics of the "Outside" (University of Minnesota Press, Minneapolis, MN) 